\title{
Singapore's Policy in the Asia-Pacific: ASEAN and Open Regionalism
}

\section{Lay Hwee Yeo}

\author{
Singapore Institute of International Affairs \\ 60A Orchard Road, 04-03 Tower 1, \\ Singapore 238890 \\ E-mail: layhwee.yeo@siiaonline.org \\ European Union Centre \\ 11 Slim Barracks Rise, \\ Singapore 138664 \\ E-mail: LHYeo@ntu.edu.sg
}

\begin{abstract}
Singapore's policies and approach towards the Asia-Pacific region are guided by conservative pragmatism dictated by two imperativesthe geographical constraints of a small city state without a hinterland or natural resources, and the constant need to stay economically competitive and politically relevant in order to survive and thrive. This chapter begins with an overview of the historical development of Singapore and then zooms in to focus on its foreign policy thinking and development approach and examines how these then translate into actual policy and posturing in its immediate neighbourhood and the broader Asia-Pacific region.
\end{abstract}

Keywords: ASEAN, foreign policy, international relations, regionalism, Singapore 


\section{Introduction}

Singapore's overall foreign policy approach could be termed as conservative pragmatism. The country's approach to foreign policy is informed primarily by the realist perspective of the international system, the centrality of state as the key actor, and the need to be vigilant and relevant to survive in this system. At the same time, it utilizes a range of tools and instruments, from building a strong military, to a pragmatic approach towards cooperation, active participation in multilateral institutions to emphasizing the international norms and principles as embodied in the United Nations (UN) Charter.

Singapore may be a small state but, through its successful economic development and astute foreign policy, it has transformed itself into a global city with growing international presence and influence. In the Global Presence Index, compiled by the Spanish Elcano Royal Institute, Singapore ranked 17th in 2012, ahead of all its Southeast Asian neighbours and several developed western economies. Here, global presence is divided into three areas, which in turn are composed of diverse indicators: economy (energy, primary goods, manufactures, services and investments); defence (troops and military equipment) and soft presence (migration, tourism, sports, culture, information, technology, science, education and development cooperation). While this presence may not necessarily translate to power and influence, it is still impressive for a small nation-state less than 50 years old then.

Singapore's policies - foreign or otherwise - are dictated by two imperatives: the geographical constraints of a small state without a hinterland or natural resources, and the constant need to stay economically competitive and politically relevant in order to survive. It is evidently informed by a deep sense of vulnerability and a strong desire to survive against all odds. This vulnerability was felt intensely especially in the earlier years of its independence because of the history of confrontation launched by its bigger neighbour, Indonesia, and the unhappy period of merger with the Malaysian Federation (1963-1965), which finally resulted in separation and the birth of a fully independent Singapore in August 1965 . Singapore is a predominantly Chinese state ( $75 \%$ of its population are ethnically Chinese), and it is surrounded by two significantly larger states, Indonesia and Malaysia, whose majority populations are ethnically Malay and primarily Muslims. Indeed, already in 1970s, Singapore's presence in Southeast Asia has led Iain Buchanan (1972, p. 19) to note that "Singapore is an aberration in Southeast Asia since its ethnic composition as well as the basis of its economic development differs significantly from other Southeast Asian states". 
Singapore celebrated its 50 years of independence in 2015 and has come a long way to become an economically successful global city. Yet, despite the prosperity and relative peace in the region, the leaders of Singapore have constantly reminded its citizens to be vigilant, and not to take its success for granted. The vulnerability discourse is still very much in vogue today. The geopolitical and geo-economic tensions resulting from the increasing US-China strategic rivalry in the last few years only reinforced the sense of vulnerability. Being a small country ruled by the same political party, the People's Action Party (PAP), since its independence, has left an indelible mark on the way policies are made and carried out. Long-term planning, underpinned by pragmatism and an abiding sense of vulnerability, was the hallmark of the government's approach towards the development of Singapore.

The conduct of foreign policy is tied very much to developments to ensure the long-term survival of Singapore as a sovereign state. This contribution will begin with an overview of Singapore's development before focusing on its foreign policy and examination of Singapore's overall foreign policy thinking and development approach, and how these translate into its posturing and actual policy towards its immediate neighbourhood and the broader Asia-Pacific region.

\section{1 "The little red dot"}

Singapore is an island state of 718 square kilometers (up from the 581 square kilometers when it first gained independence due to ongoing land reclamation projects). A former British colony, it was granted self-rule in 1959, and declared independence from the British in August 1963 to join the Federation of Malaysia. Singapore under Lee Kuan Yew then chose to join Malaysia because of communist threats and concerns over its economic viability because of its small size, lack of water and natural resources. However, for various reasons, not the least of which are the ideological differences, clashes of leading political personalities, and ethnic tensions, Singapore was asked to leave the Federation. On 9 August 1965, Singapore became a newly independent state and immediately sought to join the UN to cement recognition of its independence.

Singapore was able to leverage on its strategic geographical location with a natural harbour and build on its role as a regional entrepôt under the British rule to become a transport, shipping and trading hub. Its small population size and its lack of natural resources forced the country to adopt a very open approach towards global trade and investments. While many developing countries in the 1960 s and early 1970s sought to limit foreign investments and pursue import substitution strategy to protect its own infant industries, Singapore actively courted foreign investments and, in addition, embarked on a state-led 
drive towards industrialization to build up its economy. Its economic policy is premised on the broad framework of globalization, and the need to transcend its limitations to become a global city.

Historically, trade was the fundamental reason for Stamford Raffles of the East India Company to "lease" Singapore from the Malayan sultanate that ruled the population then. When Singapore became independent in 1965, its foreign minister in its first major policy speech stated that "the promotion of trade with as many countries as possible will be a major objective" of Singapore's foreign policy (Chan \& U1 Haq, 2007, p. 279). Singapore made it clear right from the day of its independence that it would trade with any country that was willing to trade with it and would not let ideological differences stand in the way. In his thesis, Ting (2010) argued that Singapore's conception of itself as a trading state influenced how it formulates and implements its foreign policy. The implication of being a trading state is that "it seeks order" and invests much in achieving a "durable and stable balance of power in its environment" (Ting, 2010, pp. 62-73).

Trade is indeed an important lifeline of the Singapore economy, and the country has the highest trade to GDP ratio in the world at over 300\%. This is also why Singapore is an ardent supporter of the World Trade Organization (WTO) and global free trade, hosting the very first WTO Ministerial meeting in 1995. At the same time, while supporting multilateral trade liberalization, Singapore also hedges its bets on free trade by actively pursuing bilateral and plurilateral free trade agreements (FTA) in every part of the world. It has an active FTA policy having negotiated and concluded FTAs with all its major trading partners - the European Union (EU), the USA, China, Japan, and a whole array of agreements with partners near and far.

In a significant addition, Singapore inherited from Britain the Westminster Parliamentary system. Its electoral system is based on first-past-the-post system, and this coupled with several other reasons and developments have resulted in the domination of the People's Action Party (PAP) since independence. The PAP came to power in 1959 as a coalition of a highly competent but elitist group of western-educated professionals led by Lee Kuan Yew, who sought the support of the island's Chinese-educated majority through alignment with radical trade unionists linked to the then Communist Party of Malaya (CPM). Once in power, the PAP set about the task of carefully managing the development of Singapore. Every social or political group that might have constituted an independent voice in Singapore was either co-opted, intimidated or eliminated during the first decade or so of PAP rule. Alternative paths or options were therefore systematically eliminated (Yeo, 2010a). 
Because of the strong political leadership and this long, uninterrupted rule by the PAP, policymakers could take a long-term approach towards economic and urban planning. Together with the generally benign and stable regional environment, Singapore has been able to make a remarkable economic transformation from third world to first in just four decades. By the time Singapore celebrated its 50th birthday, the country had evolved into a highly competitive and diversified market economy. Singapore is ranked consistently in the top three positions by different agencies on economic freedom and competitiveness. It has built up large foreign reserves and is now the fourth largest financial centre in the world. Its GDP per capita has risen to 51,709 US dollars from that of 516 US dollars in 1965. In addition to these economic figures and key infrastructural developments, Singapore has also done well in human development, scoring 0.895 in the UN Human Development Index with a 2012 ranking of 18th out of 187 countries and territories. The nation's educational and health achievements, and life expectancy of its population, surpassed several OECD countries.

Singapore also boasts a well-equipped and modern military force supported by its citizens' reserve trained through military conscription. All Singapore men are conscripted to the military for two years, and they remain in the reserves until the age of 50. Defense spending as percentage of GDP is among one of the highest in the world. Because of its limited land and air space, the Singapore armed forces trained in friendly countries and territories like Brunei and Taiwan, and the Republic of Singapore Air Force (RSAF) maintains a number of overseas air bases in Australia, France, India and the USA. The defence philosophy is one that is based on total defence and deterrence. Total defence here encompasses economic, military, social, civil and psychological defence. For Singapore, military capability, together with economic success, social cohesion and a resilient population is the key to its long-term survival.

Singapore spends a significant amount of its budget to acquire and develop advanced military technology and equipment. However, growing military strength while itself a source of strength can also be a double-edged sword as realists posit the classic security dilemma where any defensive attempt by a state to increase its own security can be interpreted as an offensive measure that reduces the security of its neighbouring state. As a small country, Singapore is keenly aware of its limitations in material hard power. Hence, it has significantly invested in diplomacy, having established diplomatic relations with 187 sovereign states and participated in all major multilateral forums and international institutions. Singapore is a founding member of the Association of Southeast Asian Nations (ASEAN) and an initiator of various multilateral platforms, from the Asia-Europe Meeting (ASEM) to the Global Governance 
Group ( $3 \mathrm{G})$ to encourage dialogue and cooperation. It is also active in the UN, having been non-permanent UN Security Council member in 2001-2002, and its diplomats being called to chair UN conferences such as the UN Conference on the Law of the Sea (UNCLOS) and the Rio Conference.

Yet, despite all these achievements and economic success, Singapore continued to feel a deep sense of insecurity, because of both geo-political and geoeconomic reasons. While relations with its two nearest neighbors, Malaysia and Indonesia, have improved considerably, it was also not so long ago that Singapore was reminded by the then President of Indonesia Habibie, that it remained a "little red dot in a sea of green", alluding to the fact that Singapore is a small island state with a majority Chinese population in a region that is predominantly Muslim (Asian Wall Street Journal, 1998). Up to the 1980s, Malaysia also regularly "threatened" the revision of the Water Agreements signed in the 1960s to supply untreated water from Malaysia to Singapore whenever it was politically expedient to do so. This was also the reason why the Singapore government had made such a strategic decision to invest early on in expensive research and technology to recycle water and build desalination plants. Even with three decades of uninterrupted growth, the issue of economic and political survival remains embedded in the national consciousness largely because of constant exhortation by the leaders of the need for Singapore to stay ahead of the competition or be doomed.

While Singapore's siege mentality and abiding sense of insecurity and vulnerability are very much related to the geographical reality of being a predominantly ethnic-Chinese island wedged between two larger Malay neighbours, and to its miniscule size, they are rooted also in part in the tenets of social Darwinism - the survival of the fittest - imbibed by its founding Prime Minister, Lee Kuan Yew. In 1966, he pronounced that "societies like ours have no fat to spare. They are either lean and healthy, or they die. We have calculated backwards and forwards [...] that our best chances lie in a very tightly organized society." (ST, 2006) Singapore's dependence on trade and foreign investments is also a source of vulnerability. It is susceptible to global shifts in economic fortunes and has to constantly change and adapt to remain economically relevant and competitive. Any retreat from globalization and free trade would have significant impact on the Singapore's economy. It is against this backdrop that we will next examine Singapore's approach towards regionalism and its policy in the Asia-Pacific region. 


\section{Singapore's early approach towards ASEAN and its region}

Although Singapore is one of the ASEAN's founding nations, "membership of ASEAN was not valued as a diplomatic asset in its early years" (Leifer, 2000, p. 39). To understand why this was the case, one needs to understand the context in which ASEAN was founded and Singapore's relations with the other founding members, in particular Malaysia and Indonesia, where relations up to even recent decades were colored by ethnic considerations. The organization was founded on 8 August 1967, at the height of Cold War tensions, and with regional disputes, particularly the Konfrontasi unleashed by Indonesia in 1963 against its smaller neighbours, Singapore and Malaysia, still fresh in memory. Against this background, the original aim of ASEAN as envisaged by its founding members was modest - to keep the peace in Southeast Asia through respect for each other's sovereignty and adherence to the principle of non-intervention. ASEAN was to be a forum, a tool for member states "to manage common threats of communist insurgencies while balancing internal sensitivities and conflict" (Lee, 2007).

Both intraregional and extraregional relations were to be guided by these principles of sovereign equality, respect for diversities and non-interventioninternally to build confidence among its members and externally, to present a united façade against any possible external interference from outside powers. As S. Rajaratnam, then Foreign Minister of Singapore said in his speech at the founding of ASEAN in 1967, ASEAN was not a grouping against anyone, but simply an instrument to protect the small nations of Southeast Asia from the "balkanization of the region" by outside powers (cited in Acharya, 2008, p. 124). In his later speeches, he repeatedly reminded that the major motivation for setting up ASEAN was fear of a triumphant and expansive communism, and fear of being "manipulated, set against one another, and kept perpetually weak, divided and ineffective by outside forces" (cited in Kwa, 2006, p. 91).

The common fear of communism and external interference kept the members together, suppressing but not eliminating their lingering suspicions of one another. Several ASEAN member states' regimes were pre-occupied with internal challenges, especially active insurgencies and societal cleavages with potential for eruption. Hence, the wish for a secure external environment and a united front so that states can fully concentrate on domestic developments to build up "national resilience". Indeed, the very motto of ASEAN was national resilience for regional resilience, the fundamental belief that individual member states need to be strong for the region to be resilient against outside threats. The 
states fulfill the promises to refrain from interference and to respect each other because the regional organization unites them in a higher common interest-a relatively peaceful and stable environment.

In the first decade of ASEAN's existence, ASEAN's growth as a regional organization proceeded very slowly. Singapore only came to appreciate the political advantage of ASEAN as a vehicle for intra-mural confidence building as its relations with Indonesia began to improve. Singapore's attitude towards ASEAN further improved because of this qualitative change in its relationship with its biggest neighbour, Indonesia. External events in the region, with the victory of the communists in Vietnam and the spread of communism in Indochina, was also a driving force that made Singapore realize the importance of having ASEAN as a "protective diplomatic vehicle" to signal that members in ASEAN would stick together and not fall victim to the communist forces (Leifer, 2000, p. 79).

However, even as Singapore participated more actively in forging an ASEAN diplomatic identity, it had no illusions about the security guarantee it could expect from ASEAN since the organization was never meant to be a defence alliance. Hence, in dealing with its security, Singapore took a more pragmatic approach in anchoring the USA as a major player in the region to forestall any undue dominance by any regional power. Singapore is a strong proponent of US presence in the region to prevent any of its neighbouring countries from becoming a regional hegemon. This preference for the USA's presence is premised on its distrust of its neighbours and the fear that regional states are more likely to try to assert dominance over it. While recognizing that Singapore is an integral part of Southeast Asia, it also sought to transcend its neighbourhood by actively drawing in outside major powers such as US into the Southeast Asian theatre.

ASEAN was not originally set up to pursue regional integration, and regionalism was not in vogue in the Southeast Asian region in the early years of the organization. ASEAN thus made little progress in economic cooperation until the post-Cold War era when it was faced with increasing economic challenges with the opening up of China and India. It did try in the 1970s, after its first inaugural Summit meeting in Bali in 1976, to engender closer economic cooperation. The Declaration of ASEAN Concord, signed in 1976, set out the guidelines for concrete regional economic relations. Following this, a number of initiatives and agreements were launched, the most notable of these were the ASEAN Preferential Trading Agreement aimed at liberalizing trade, the ASEAN Industrial Projects Programme to build and encourage joint ventures among ASEAN companies, and the ASEAN Industrial Complementation 
scheme aimed at promoting intra-ASEAN investments.However, all these economic endeavors never took off, as they were perceived to run counter to respective national interests. Indeed, the low compatibility and complementarity of ASEAN economies then discouraged ASEAN governments from taking ASEAN economic integration further. The Vietnamese invasion of Kampuchea (Cambodia) in 1978 provided ASEAN with something to focus their attention on. Political and diplomatic energy were invested in facing up to this immediate threat.

With barriers still high in regional economic endeavors, Singapore's economic policy from 1970 to 1990 was geared towards "globalization" in the sense of active participation in the global economy rather than a regionalization strategy. During these two decades, as argued by Acharya (2008, pp. 36-41), "Singapore's trade shifted away from Southeast Asia to become increasingly global [...], [while] [t]he international orientation of Singapore's economy is also evident in the degree to which it relies on foreign investments from the developed economies of Europe, US and Japan". Thus, in the area of economics, Singapore also actively pursued a multi-tiered approach to diversify its links and transcend the region.

This often talked about strategy to leapfrog or transcend the region had at times irritated its neighbors. Yet, Singapore has never been shy of its ambition to be a global city and to transcend the inherent geographical limitations. The Foreign Minister of Singapore, Rajaratnam first coined the concept of Singapore: Global City in a speech in 1972, and called on its citizens to view Singapore's future not as a regional city but as a Global City, and to transcend the limitations of the absence of a hinterland by seeing "the world as its hinterland" (as cited in Kwa, 2006, p. 172).

From above, one sees that Singapore in its earlier years was not a strong advocate or believer in ASEAN regionalism. In the 1970s, as relations with Indonesia improved, "Singapore was willing to go along with the prerogative regional outlook of Indonesia in promoting the corporate identity of ASEAN" (Leifer, 2000 , p. 81). As ASEAN developed a habit of dialogue that led to an evolution of healthy intraregional diplomatic ties, in the next stage of development, the ASEAN countries also succeeded in forging a greater consensus of views on various global and regional issues. This is particularly the case after 1978, following Vietnamese invasion of Kampuchea (Cambodia). ASEAN began to speak with one voice in international fora. Its success in the politico-diplomatic sphere was most obvious in its relentless pressure on Hanoi to reverse the latter's action in Cambodia. Singapore played an important part in "promoting 
and coordinating the diplomacy of the ASEAN states" during the decade in opposing Vietnamese invasion and occupation of Cambodia (1978-1988), but it was only at the end of the Cold War that "Singapore came out of its diplomatic shell to assert a managerial role in regional politics" (Leifer, 2000, p. 84) and to promote the ASEAN brand of regionalism.

With the sweeping changes brought about by the end of the Cold War, Singapore began to see regionalism as a useful instrument to manage increased economic competition. The unpredictability of post-Cold War geopolitics was certainly challenging. Of particular significance were the economic challenges arising out of the crisis in the international trade regime and shifting balance of power in the Asia-Pacific region with the re-emergence of China and India (Acharya, 2008, p. 32).

\section{Post-Cold War environment, open regionalism and ASEAN centrality in the Asia-Pacific}

The end of the Cold War brought about opportunities but also challenges to Singapore's policy. While the Cold War period had its moments of tensions and dangers, there was a greater degree of predictability and balance maintained as long as ASEAN remained under the "Western orbit". The US bilateral alliances in East Asia, its bases in the Philippines and close military cooperation with several of the other ASEAN member states provided a relatively manageable framework of international relations for Singapore to operate in. In contrast, the post-Cold War environment initially hailed by the West for unleashing a new wave of democratization, and clamor towards greater institutionalization of international norms and institutions, created uncertainties for Singapore. Intensified economic competition, and a more robust human rights and democratization agenda pursued by the US and its European allies in the postCold War environment, coupled with the opening up of the China, and the Look East policy pursued by India in the early 1990s, brought about a series of responses from Singapore and ASEAN.

Faced with increased economic competition, ASEAN responded with the decision to establish an ASEAN Free Trade Area (AFTA) in 1992. To cope with the changing regional security environment with the uncertainties over the US presence and its security commitments in Southeast Asia, Singapore worked within ASEAN to launch the ASEAN Regional Forum (ARF), the first AsiaPacific wide forum for political and security dialogue. The ARF, together with 
other multilateral frameworks such as the Asia-Pacific Economic Cooperation (APEC) forum and the ASEM, were used to better engage China.

With the West's optimism towards multilateralism and cooperative security in the post-Cold War era, Singapore was able to seize the opportunity to build on the collective diplomacy of ASEAN developed during the Cambodian crisis and engage the wider Asia-Pacific as an anchor for the growing economic and security interdependence. As Acharya (2008, p. 30) noted, the realist view of Singapore in international relations was "moderated by a recognition of the opportunities for multilateral cooperation and institution building".

\subsection{Open regionalism and transregional forums}

With growing trade, economic interdependence and internationalism, a new wave of thinking on regionalism began to emerge in the Asia-Pacific in the 1980s. This new wave of regionalism was in stark contrast to the inward-looking process of building an exclusive integrated bloc epitomized by the European integration project that had begun in the 1950s. In the Asia-Pacific region, regionalism was more outward-looking and focused on building links with other regions. Instead of forming a closed bloc, the new regional bloc acted as catalytic agent, between nationalism and internationalism. This regionalism was not a movement toward territorially based autarkies like those of the 1930 s, nor was integration necessarily the end goal as with the EU. Rather it represented concentrations of political and economic power competing in the global economy, with multiple interregional and intraregional flows (Mittelman, 1996, pp. 189-213).

In the Asia-Pacific, this new wave of regionalism led to the founding of the APEC in 1989. APEC was in fact built on the basis of "open regionalism", a concept taken to mean a non-exclusionary approach towards building regional economic blocs that are compatible with the global trading system, and can be building blocks for further global liberalization (Bergsten, 1997). Comprised initially of 12 economies (Australia, Canada, Japan, Korea, New Zealand, the USA and ASEAN 6-Brunei, Indonesia, Malaysia, Philippines, Singapore and Thailand), APEC was an initiative from Japan and Australia for a regional bloc as they face tough negotiations with the European Community in GATT (General Agreement on Trade and Tariffs) during the Uruguay Round.

The end of the Cold War provided further impetus to expand this new open regionalism. With the breakdown of the overarching Cold War structure, states were forced to evaluate their place in the new international system. On the context, Wyatt-Walter noted, 
As the common security linkages that helped to underpin post-World War II economic cooperation between Western Europe, US and Japan were eroded, economic competition and the conflicts between different forms of capitalism as practiced in these places intensified and became more visible. The collapse of the Soviet Union also brought new security threats arising from political and economic instability within regions to the global agenda. These included issues such as fair trade, weapons proliferation, mass migration and environmental degradation. (Wyatt-Walter, 1995, p. 93)

Many states also began to appreciate anew how much their own welfare was affected by the stability and economic well-being of the region in which they were located. The collapse of the bipolar system and the decentralization of the international system strengthened the case for regionalism. Buzan (1994, pp. 9495) noted that the removal of the old overlay patterns of great power influence encouraged multipolarity and contributed to an emerging international system in which regional agreements can be expected to assume greater importance. The new felt independence in the aftermath of the Cold War brought about bolder initiatives and experimentation on regional cooperation, particularly among developing countries. At the same time, the newly found independence also generated a sense of vulnerability as a power vacuum appeared and uncertainties about the new emerging order set in. Regionalism was one way to cope with this. Much of the new wave of open regionalism was focused on intergovernmental transregional and interregional dialogue and cooperation.

Singapore's policymakers are cognizant of these developments and shifting interests, and its policies are geared to deal with the new realities. Singapore has thus embarked on a policy of actively supporting economic regionalization and making a concerted effort to strike a balance between globalism and regionalism. The country was active in promoting the various forums that bring about the dialogue and cooperation between the Western developed economies and East Asia modeled on the ASEAN Way. Besides the ARF, Singapore has also played a significant role in conceptualizing the ASEM, a platform for leaders of ASEAN plus China, Japan and Korea to meet with the leaders of the EU. Though Singapore was not the mastermind behind APEC, which was founded in 1989, it began to take an active interest in promoting APEC after the inaugural summit in 1993.

Singapore's support for open regionalism and ASEAN regionalism was also in tune with the general shifts of the economic outlook and the policies pursued by ASEAN members. As discussed earlier, since its independence Singapore 
has opened its economy to Western trade and investments and pursued a global city strategy to secure their presence. In contrast, most ASEAN members flirted with a more protectionist import substitution strategy. However, by the 1980s, most had shifted towards greater acceptance of the neo-liberal economic regime of free trade and welcoming foreign investments. As its neighboring countries started to lower the barriers towards trade and investments and experienced respectable growth rates, opportunities for Singapore to strengthen economic links with its neighbours open up. By the early 1990s, ASEAN countries were highly competitive and able to attract significant investments. The upward trend of the ASEAN economies was brought to a halt by the Asian financial crisis in 1997-1998. While several of the ASEAN economies were able to export their economies back to health within three to five years, they had lost their competitive edge and started to lag behind in competitiveness and attractiveness to other emerging markets, in particular China.

To revitalize ASEAN's economic fortunes and strengthen coordination in response to globalization and the challenges from China, Singapore urged its fellow members in ASEAN to move towards creating an ASEAN Economic Community. This culminated in the idea of achieving an ASEAN Community by 2015. Singapore's stake in ASEAN has increased. The rise of China and its increasing presence in the Asia-Pacific has led to complex issues and linkages between economic and security regionalism. To cope with this challenge, Singapore began to take on an even more active role within ASEAN, and in conjunction with other partners, in particular Indonesia, tried to ensure ASEAN's relevance and centrality in managing the increasing complex situation in the Asia-Pacific.

Much of Singapore's regionalization strategy was effected through ASEAN, and in the aftermath of the Asian financial crisis, also the ASEAN+3 (APT) framework and the East Asia Summit (EAS). With the rise of China and India, Singapore increasingly sees its survival as very much tied to the developments in Asia. Singapore has actively engaged China and India not only on bilateral basis but has also assiduously leveraged on ASEAN to manage the rise of China and India, and to bring these two giants into the various ASEAN-centric frameworks. Its strategy for long-term survival is to support the greater integration of Chinese and Indian economies into the regional and global economy. 


\subsection{The ASEAN Economic Community, APT and economic regionalism}

Singapore was one of the main instigators pushing for an ASEAN Economic Community (AEC). The AEC is a response to the global economic landscape that changed dramatically after the 1997 financial crisis. The loss of economic competitiveness, the challenges posed by China and India, and the increasing importance of production networks in the regionalization of East Asia made it imperative for ASEAN to deepen its economic cooperation. While the ASEAN Free Trade Agreement (AFTA) has succeeded in bringing down tariffs for a number of manufactured goods, non-tariff barriers remained a major obstacle to the free flow of goods and a number of service industries remained highly protected.

A McKinsey study in 2003 found that middle-income ASEAN countries are no longer competitive and that the region needs to look for new sources of growth. One key recommendation that came out of the McKinsey study was for ASEAN to pursue deeper integration in order to take advantage of complementarities between the ASEAN economies to achieve economies of scale, industrial efficiency and productivity. As Yeo (2010b, p. 219) noted, "[r]egional production networks need to be revitalized and the nexus between trade and FDI needs to be emphasized". The AEC was in part a logical extension of AFTA and a number of economic initiatives such as the ASEAN Investment Area (AIA) and ASEAN Framework Agreement on Services (AFAS) that were discussed throughout the 1990s and early 2000s.

Reflecting the pro-trade policy and open regionalism idea favored by Singapore, ASEAN also embarked on a number of FTAs and comprehensive economic cooperation agreements. Agreements were signed in quick succession with China, Japan, South Korea, Australia and New Zealand and India. Beyond the encouragement from Singapore, there are several other reasons for the proliferation of FTAs in ASEAN. The Asian financial crisis revealed the extent of economic interdependence between Southeast Asia and Northeast Asia, which also catalyzed closer cooperation leading to the creation of the APT framework.

The APT framework, which comprised ASEAN plus China, Japan and South Korea and was launched in 1997, made good progress in promoting Southeast Asia and Northeast Asian cooperation for 20 years before being overshadowed by the EAS and the rising tensions between China and Japan. Within a few years, the APT catalyzed the negotiation and conclusion of the ASEAN-China FTA and ASEAN-Japan FTA. More importantly, during the APT finance ministers meeting in Chiangmai in 2000, agreement was reached on a currency swap scheme, a milestone in East Asian cooperation in the sphere of finance. 
When the global financial crisis hit in 2008-2009, the East Asian countries agreed to multilateralize this network of bilateral currency swap agreements. An economic surveillance unit known as the ASEAN+3 Macroeconomic Research Office (AMRO) was also established as part of the support for the functioning of deeper monetary cooperation (Lai \& Ravenhill, 2012, pp. 144-145).

The stalled trade negotiations in the WTO and the rapid rise in intra-Asian trade driven by China's and India's rise and the recovery of those economies affected by the Asian financial crisis also leads to greater ambitions for regionwide FTAs. Negotiations also now under way for a Regional Comprehensive Economic Partnership that would tie up the various ASEAN+1 agreements to ASEAN+6 (China, Japan, Korea, Australia, New Zealand, and India). However, Singapore is also keenly aware of the limitations of many of these ASEAN FTAs as they generally trade light and negotiate for more political rather than economic considerations. Hence, while it actively participates in these fora, it has also its own bilateral trajectory for pursuing high quality FTAs to further cement its access to various important markets.

\subsection{The ASEAN regional forum and ASEAN's centrality}

The strategic uncertainties brought about by the shifts in major power relations with the end of the Cold War and the rise of China in the early 1990s were a concern for several ASEAN member states. On the back of the confidence, which stemmed from the sterling economic growth of its member states, ASEAN began to speak of a need for a wider Asia-Pacific forum that could address some of the fears and uncertainties of a region in flux. ASEAN leaders agreed to use and extend the existing ASEAN Post-Ministerial Conference (PMC) as the forum for promoting political and security dialogue with countries across the Asia-Pacific region (Caballero-Anthony, 2005, pp. 114-128).

The modalities for the forum were further deliberated and planned during ASEAN meetings and agreed on in 1993. In 1994, the inaugural ARF meeting comprising initially of 18 member states (the ASEAN-6, Australia, Canada, China, the European Community, India, Japan, New Zealand, Papua New Guinea, Russia, South Korea, the USA and Vietnam) was convened. The ARF is modeled upon the ASEAN way of consultation and consensus-building which ASEAN believes can be applied to the larger region. The general approach is to first focus on dialogue to build trust and confidence, and foster habits of cooperation. This will then lead to preventive diplomacy followed by genuine conflict management contributing to peace and stability in the region (Narine, 2002, pp. 106-113). 
ASEAN currently occupies a central role in the Asia-Pacific, particularly in East Asia because of "the unique qualities of the East Asian environment in which ASEAN operates" (Narine, 2009, p. 370). The major powers in East Asia, Japan and China do not trust each other for historical reasons and, additionally, due to on-going tensions over the Senkaku or Diaoyu islands in the East China Sea. The Asia-Pacific also constitutes a "unique security environment" with major powers (the US, China, Japan, and, to some extent, Russia and India) competing with one another for influence. These rivalries created "a political space within which ASEAN may exercise significant regional influence" and enhance its own strategic importance. However, whether ASEAN can "exploit this advantage is partly contingent on the organization's internal unity" (Narine, 2009, p. 370). ASEAN needs to move towards deeper integration if it wants to hang on to its centrality in the region.

The question of whether ASEAN's centrality in the broader region is one of default rather than leadership has often been raised. ASEAN's solidarity and ability to drive the regional processes have been increasingly questioned over the last few years. So far, ASEAN has been able to maintain a central role in the various regional architectures by default because the major powers in the region have abstained from leadership for fear of arousing suspicion from their rivals. However, as the USA and China, and China and Japan step up their competition in the region more openly, and as some ASEAN member states felt increasingly threatened by China over the claims in the South China Sea, there is a danger that ASEAN itself may be divided.

East Asia, the broader region in which ASEAN is situated, has moved to become a dominant world region where the core dynamics globally are now central to the dynamics of the region. This is true in terms of the shifts within global capitalism and of the geopolitical centrality of 21 st-century major power politics, including, of course, US-China relations. While the USA remains dominant in the global order, its leadership is increasingly challenged, and it can no longer act alone to achieve its goals. China is an important emerging power. Particularly in the Asia-Pacific region, Sino-US relationship will be the core consideration for any regional order. There are very powerful external pressures on ASEAN to maintain itself as an effective manager of regional order (Goh, 2007). On the one side is the importance of building regional multilateral institutions that serve to regulate exchanges, develop norms, and institutionalize cooperation, including the incorporation of a rising China. On the other side is indirect balancing vis-à-vis China by facilitating continued US security commitment. The increased economic interdependence and the growing dependence of many Southeast Asian countries on the Chinese economy exist 
alongside the increasing security concerns that these countries have with regard to a rising China. This growing concern has sparked calls for a heightened US presence, reflecting the fundamental dichotomy between economic regionalism and security regionalism in the Asia-Pacific region.

Singapore is well aware of this conundrum. While in the economic arena, Singapore's strategy is to forge global and regional economic interdependence, in the area of security, Singapore still very much seeks a balance of power approach. Singapore makes it clear that it does not want to be pushed to choose between the US and China, which is also officially the position of ASEAN. However, with increasing tensions in the South China Sea, some members of ASEAN may be prepared to deviate from this position. The increasing strategic rivalry and tensions between the US and China are becoming an uncomfortable situation for ASEAN and its member states.

Singapore is now entering into a post post-Cold War world where the global economic and security situation, in contrast to the immediate post-Cold War period, has become less optimistic. American ability to maintain the international order is declining in the aftermath of the drawn-out wars in Afghanistan and Iraq and the financial and debt crisis of 2008-9. This coupled with the rise and reemergence of powers like Brazil, China, India and Russia, the general diffusion of power, increased fragmentation of the world and a host of challenges arising from climate change, scarcity, etc., portend an increasingly unpredictable and volatile world. Despite Singapore's success in building an economically developed and politically stable country, Singapore's foreign policy needs to keep pace with changes and be nimble and flexible and geared toward overcoming vulnerabilities, both old and new.

\section{Conclusion}

The prognosis for an independent Singapore when it was kicked out of Malaysia in 1965 was not good. It has no natural resources, no hinterland and had to rely on Malaysia for its water supply. With a small population, small market size and limited land, it has managed to overcome these handicaps to become one of the most developed countries in the world today. Singapore has surmounted geographical obstacles and embraced policies that transcend inherent limitations; by opening up to the world, it has made itself relevant. 
Conservative pragmatism has guided Singapore's policymaking since its independence. Though there are several scholars, such as Michael Leifer, who classified Singapore as a realist in its approach towards international relations and politics because of its hard-nosed approach towards power and interest, realism alone cannot adequately explain Singapore's foreign policy in the AsiaPacific. In fact, Singapore employs an eclectic mix of approaches, which this article treats as pragmatism, to ensure the best outcome for Singapore. The country understands the constraints of structural power that limit what a small state can do, and often self-effacingly refers to itself as a price-taker, yet it actively participates in multilateral institutions and creates new institutions to ensure its voice is heard. It is conservative in the sense that it places the highest value on order (which is often seen as the pursuit of balance of power) and not on the liberal pursuit of justice and liberty. Yet, it is a mistake to view Singaporean foreign policy as merely ensuring its survival through power-balance. As Amitav Acharya (2008, p. 118) argued, "it has also been about carving out a regional existence through socialization within regional institutions and processes" as reflected in its later activism in ASEAN and various ASEAN-centric frameworks.

Singapore's realism does not allow it to be lulled into believing Francis Fukuyama's thesis that the world is moving towards universalization of values and that globalization has redefined the nature of power and international affairs. In responding to the events in Ukraine, the former permanent secretary of the Singapore's Ministry of Foreign Affairs wrote in an op-ed that while a world ruled by international law is the ideal world for small states, the truth is that "international law is an instrument of state policy, not an autonomous reality. Great powers resort to it only when convenient." He went on to reiterate the importance of our national service commitments and warn that "we must never lose the ability to look after ourselves, because if we cannot look after ourselves, nobody will look after." (Kausikan, 2014)

\footnotetext{
Dr. Yeo Lay Hwee is director of the European Union Centre in Singapore, senior research fellow at the Singapore Institute of International Affairs, and adjunct research fellow at the S Rajaratnam School of International Studies. She also sits on the advisory boards of the Centre for European Studies at the Australian National University and of the KU Leuven's Master in European Studies (MAES) Programme. An international relations expert, her research interests revolve around comparative regionalism; developments in the EU and ASEAN, and on Asia-Europe relations. She participates actively in both academic conferences and policy dialogue and is active in networks such as the Agora EU-Asia Network. She is also the co-editor-in-chief of the Asia Europe Journal, published by Springer.
} 


\section{References}

Acharya, A. (2008), Singapore's Foreign Policy: The Search for Regional Order, New Jersey, London \& Singapore: Institute of Policy Studies and World Scientific.

Bergsten, C. F. (1997), Open Regionalism, IIE Working Paper, no. 97-3, Peterson Institute for International Economics. Retrieved from: http://www.iie.com/ publications/wp/wp.cfm?ResearchID=152 [accessed 24 Mar 2014]

Buchanan, I. (1972), Singapore in Southeast Asia: An Economic and Political Appraisal, London: G Bell \& Son Ltd.

Caballero-Anthony, M. (2005), Regional Security in Southeast Asia: Beyond the ASEAN Way, Singapore: Institute of Southeast Asian Studies. https://doi. org/10.1355/9789812307095

Chan, H. C. \& Obaid U. H., eds. (2007), S. Rajaratnam: The Prophetic and the Political, 2nd ed., Singapore: Institute of Southeast Asian Studies.

Kausikan, B. (2014), 'Lessons for small states from Ukraine,' The Straits Times, 5 March.

Kwa, C. G., ed. (2006), S. Rajaratnam on Singapore: From Ideas to Reality, Singapore: World Scientific \& Institute of Defence and Strategic Studies. https://doi.org/10.1142/9789812772404

Lai, J. \& Ravenhill, J. (2012), 'Asia's multi-level response to the global financial crisis,' Asia-Europe Journal, vol. 9, no. 2, pp. 141-157. https://doi.org/10.1007/s10308-012-0305-7

Lee, H. L. (2007), 'Speech at the ASEAN Day Lecture,' The Straits Times, 8 August.

Leifer, M. (2000), Singapore's Foreign Policy: Coping with Vulnerability, London \& New York: Routledge.

Mittelman, J. H. (1996), 'Rethinking the New Regionalism in the context of globalization,' Global Governance, vol. 2, no. 2, pp. 189-213. https://doi.org/10.1163/19426720-002-02-90000004

Narine, S. (2002), Explaining ASEAN: Regionalism in Southeast Asia, Boulder, CO \& London: Lynne Rienner Publication.

Narine, S. (2009), 'ASEAN in the 21st century: a skeptical review,' Cambridge Review of International Affairs, vol. 22, no. 3, pp. 369-386. https://doi.org/10.1080/09557570903104065

Ting, M. H. (2010), Singapore's Foreign Policy: Beyond Realism, PhD thesis, University of Adelaide. Retrieved from http://digital.library.adelaide.edu.au/ dspace/bitstream/2440/71973/1/02whole.pdf [accessed 8 Apr 2014]

Wyatt-Walter, A. (1995), 'Regionalism, globalisation and world economic order,' in L. Fawcett \& A. Hurrell (eds.) Regionalism in World Politics: Regional Organisation and International Order, New York: Oxford University Press, pp. 74-121. 
Yeo, L. H. (2010a), 'Democracy and governance in Singapore: the sustainability of Singapore's political system,' in B. Bridges \& L. S. Ho (eds.) Public Governance in Asia and the Limits of Electoral Democracy, Cheltenham \& Northampton: Edward Elgar Publishing, pp. 172-191.

Yeo, L. H. (2010b), 'From AFTA to ASEAN Economic Community - Is ASEAN moving towards an EU-style economic integration,' in F. Laursen (ed.) Comparative Regional Integration: Europe and Beyond, Surrey \& Burlington: Ashgate, pp. 215-226. 